\title{
FAKTOR-FAKTOR YANG BERHUBUNGAN DENGAN KEIKUTSERTAAN \\ PASANGAN USIA SUBUR (PUS) DENGAN PENGGUNAAN ALAT KONTRASEPSI DI DESA ALAMENDAH KECAMATAN RANCABALI KABUPATEN BANDUNG
}

\author{
Agustina Ida Pratiwi \\ Program Studi Diploma III Kebidanan Sekolah Tinggi Ilmu Kesehatan Sint Carolus \\ Email : agustinap56@gmail.com
}

\begin{abstract}
ABSTRAK
Indonesia merupakan negara yang mempunyai jumlah pendudukan yang sangat tinggi. Salah satu upaya pemerintah dalam mengendalikan jumlah penduduk yaitu dengan menggunakan program KB. Akan tetapi angka keikutsertaan Pasangan Usia Subur dalam penggunaan KB diindonesia belum maksimal. Penelitian ini bertujuan untuk mengetahui faktor-faktor yang mempengaruhi keikutsertaan Pasangan Usia Subur dalam penggunaan alat kontrasepsi. Desain dalam penelitian ini adalah Analitik dengan pendekatan cross sectional yang dilakukan di kecamatan Rancabali, Alamendah, Bandung, menggunakan data primer dengan pengisian kuesioner. Populasi dalam penelitian ini adalah seluruh Pasangan Usia Subur dengan jumlah 288 responden. Uji statistik yang digunakan adalah Chi-Square. Dari hasil analisi data dari 288 responden sebanyak 210 menggunakan berpartisipasi dalam menggunakan KB sedangkan 78 tidak berpartisipasi. Hasil penelitian menyimpulkan adanya hubungan antara variabel pengetahuan, Pendidikan dan peran PLKB dengan akseptor KB, sedangkan variable pekerjaan, usia dan dan dukungan suami tidak berhubungan.
\end{abstract}

\section{Kata kunci : Pasangan Usia Subur, Penggunaan Alat Kontrasepsi}

\begin{abstract}
Indonesia is a country has a very high number of occupations. One of the government's effort to control the population is by using a family planning program. However, the participation rate of Fertile Age Pairs in the use of family planning in Indonesia is not maximal This study aims to determine the factors that influence the participation of Fertile Age Couples in the use of contraceptives. The design in this study was analytic with a cross sectional approach conducted in Rancabali sub-district, Alamendah, Bandung, using primary data by filling out questionnaires. The population in this study were all of the fertile age couples with a total of 288 respondents. The statistical test used is Chi-Square. From the analysis of data from 288 respondents, 210 used Participating in using KB while 78 did not participate. The results of the study concluded that there was a relationship between the variables of knowledge, education and the role of the PLKB and family planning acceptors, while the variables of work, age and husband's support were not related.
\end{abstract}

Keywords: Couples of childbearing age, use of contraception 


\section{PENDAHULUAN}

Indonesia merupakan negara berkembang yang peningkatan jumlah penduduknya sangat pesat. Meningkatnya Jumlah penduduk dapat menjadi masalah baik untuk negara ataupun bagi masyarakatnya sendiri. Menurut Syukur, (2010) Untuk mengatasi masalah tersebut diperlukan suatu peraturan dan kebijakan dari pemerintah agar kesejahteraan masyarakat dapat terjamin. Untuk mengatasi laju penduduk yang tidak seimbang maka diperlukan adanya program KB (keluarga berencana).

Untuk mewujudkan keluarga yang berkualitas dan pertumbunhan pendudukan yang seimbang, maka pemerintah menetapkan kebijakan keluarga berencana melalui penyelenggaraan program $\mathrm{KB}$. Menurut Undang-Undang Nomor 52 tahun 2009 tentang perkembangan kependudukan dan pembangunan keluarga, yang dimaksud dengan Keluarga Berencana (KB) adalah upaya mengatur kelahiran anak, jarak dan usia ideal melahirkan, mengatur kehamilan melalui promosi, perlindungan dan bantuan sesuai dengan hak reproduksi untuk mewujudkan keluarga yang berkualitas (UUD, 2009).

Menurut Anjum, Et al (2014) Walaupun pemeritah sudah melaksanakan program KB namun angka kelahiran masih cukup tinggi. Untuk menekan hal tersebut pemerintah menganjurkan untuk Pasangan usia Subur menggunakan metode kontrasepsi yang sudah di terapkan dibeberapa negara. Hal ini sudah berjalan dengan data dari BKKBN (2015) yang menampilkan bahwa penggunaan alat kontrasespi bertambah dalam waktu tiga tahun terakhir.

Menurut WHO (World Health Organisation, 1970) keluarga berencana adalah tindakan yang membantu individu atau pasangan suami istri untuk mendapatkan objek tertentu, yaitu : menghindarkan kelahiran yang tidak diinginkan, mendapatkan kelahiran yang memang diinginkan, mengatur interval diantara kehamilan, menentukan jumlah anak dalam keluarga. Keluarga berencana adalah suatu usaha menjarangkan atau merencanakan jumlah anak dan jarak kehamilan dengan memakai kontrasepsi (Zainuddin, 2012).

Kontrasepsi adalah upaya untuk mencegah terjadinya kehamilan. Upaya ini bersifat sementara dan dapat pula bersifat permanent. Pemakaian kontrasepsi merupakan salah satu indikator yang mempengaruhi fertilitas (Wiknjosastro, 2013). Jenis-jenis metode kontrasepsi memiliki tingkat efektivitas yang tinggi untuk mencegah kehamilan, akan tetapi efektivitas kontrasepsi juga dipengaruhi oleh beberapa faktor yaitu perilaku dan sosial budaya pemakainya. (BKKBN, 2012).

Salah satu upaya yang dilaksanakan dalam program $\mathrm{KB}$ adalah melalui penggunaan alat kontrasepsi. Berdasarkan data World Health Organization (WHO) jika dibandingkan dengan Negara ASEAN lainnya, penggunaan alat kontrasepsi di Indonesia sebesar $61 \%$ sudah melebihi ratarata ASEAN $(58,1 \%)$. Akan tetapi masih lebih rendah dibandingkan Vietnam (78\%), Kamboja (79\%) dan Thailand (80\%). Padahal jumlah Wanita Usia Subur (WUS) tertinggi di ASEAN adalah Indonesia yaitu 65 juta orang (Kemenkes, 2013).

Pasangan Usia Subur (PUS) adalah pasangan suami istri yang terikat dalam perkawinan yang sah yang umur istrinya antara 15-49 tahun (Pinem, 2009). Pasangan Usia Subur adalah pasangan suami-istri yang istrinya berumur 15-49 tahun dan masih haid, atau pasangan suami-istri yang istrinya berusia kurang dari 15 tahun dan sudah haid, atau istri sudah berumur lebih dari 50 tahun, tetapi masih haid.

Faktor-faktor yang mendukung partisipasi Pasangan Usia Subur (PUS) dalam KB menurut penelitian Kurnia (2008), meliputi kurangnya pengetahuan PUS tentang $\mathrm{KB}$, sosial budaya, akses pelayanan 
KB dan kualitas pelayanan KB. Pemakaian alat KB lebih banyak di daerah perkotaan dengan tingkat sosial ekonomi. Faktor lain yang mempengaruhi penggunaan alat kontrasepsi dapat diakibatkan karna kekhawatiran terhadap efek samping yang ditimbulkan dari alat kontrasepsi seperti terjadinya peningkatan berat badan, Peningkatan berat badan yang tidak terkontrol merupakan sesuatu yang ditakuti akseptor karena struktur tubuh menjadi jelek, tidak menarik dan menjadi faktor resiko timbulnya penyakit jantung, diabetes melitus, hipertensi.

Penggunaan kontrasepsi dapat dipengaruhi oleh tingkat pengetahuan, tingkat pendidikan, faktor ekonomi dan umur. Hasil

penelitian Wijayanti (2009), menunjukkan pemberian penyuluhan tentang KB berdampak meningkatkan minat PUS untuk ber-KB

Data BKKBN (2017) menyebutkan bahwa Pasangan usia subur 9.333.302, dan hanya $11.2 \%$ yang menggunakan alat kontrasepsi yaitu sebesar 1.029.212 Dengan pengguna kontrasepsi suntik, IUD, Implant, Pil KB, MOW/MOP dan Kondom.

Berdasarkan data yang diperoleh dari puskesmas desa Alamendah Jumlah pasangan usia subur (PUS) berjumlah 786 dengan jumlah peserta KB sebanyak 288 dan masih banyak dijumpai PUS yang memiliki anak lebih dari 2, ini sangat bertolak belakang dengan visi yang diusung oleh pemerintah dalam program keluarga nasional yaitu "2 anak cukup". Berdasarkan latar belakang tersebut, penulis tertarik untuk melakukan penelitan Faktor-faktor yang Berhubungan dengan Keikutsertaan Pasangan Usia Subur (PUS) dengan Penggunaan Alat Kontrasepsi di Desa Alamendah Kecamatan Rancabali Kabupaten Bandung.

\section{METODE}

Metode penelitian yang digunakan adalah penelitian analitik dengan rancangan cross sectional study untuk melihat dinamika hubungan variabel independen (umur, pendidikan, pengetahuan, pekerjaan, dukungan suami, dan PLKB (Petugas pelayanan keluarga berencana) dan variabel dependen (akseptor KB) pada saat yang bersamaan. Pengambilan data dengan menggunakan data primer yang diperoleh dari hasil kuesioner.

Populasi dalam penelitian ini adalah semua pasangan usia subur yang berusia 15 49 tahun yang masih mendapatkan haid. di Desa Alamendah Kecamatan Rancabali Kabupaten Bandung . Teknik sampling yang digunakan dalam penelitian ini adalah simple random sampling dengan pengundian populasi secara acak sehingga setiap anggota dalam populasi memiliki kesempatan yang sama. Jumlah sampel diambil dengan menggunakan perhitungan rumus Slovin dengan derajat kepercayaan 95\% sehingga didapatkan hasil sebesar 288 responden. (Notoatmodjo, 2010). Penelitian ini menggunakan kuesioner sebagai intrumen. Pengolahan data dilakukan dengan cara : editing, coding, processing, cleaning. Analisis data menggunakan program komputer SPSS versi 25 dan tehnik analisis Chi-Square.

HASIL

\section{Analisis Univariat}

Data umum ini menggambarkan tentang karateristik responden berdasarkan usia, pendidikan, pekerjaan, dukungan Suami, pelayanan $\mathrm{KB}$.

\section{Grafik $1.1 \quad$ Distribusi Frekuensi Responden Berdasarkan Umur}




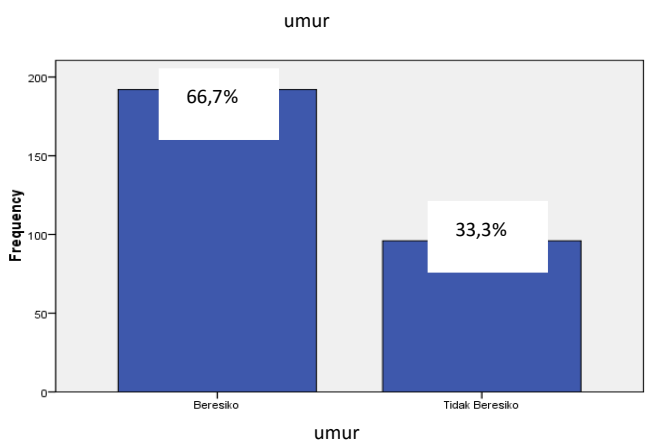

Umur responden dikategorikan menjadi dua, yaitu umur responden tidak berisiko dan berisiko. Tidak berisiko yaitu umur responden yang berumur 20-35 tahun. Berisiko yaitu umur responden berumur $<20$ tahun atau $>35$ tahun

Berdasarkan Grafik 1.1. diketahui bahwa dari 288 (100\%) jumlah responden, persentase kelompok umur tertinggi adalah kelompok beresiko sebanyak 192 responden (66,7\%) dan sisanya adalah tidak beresiko sebanyak 96 responden $(33,3 \%)$.

\section{Grafik 1.2 Distribusi Frekuensi responden berdasarkan pendidikan}

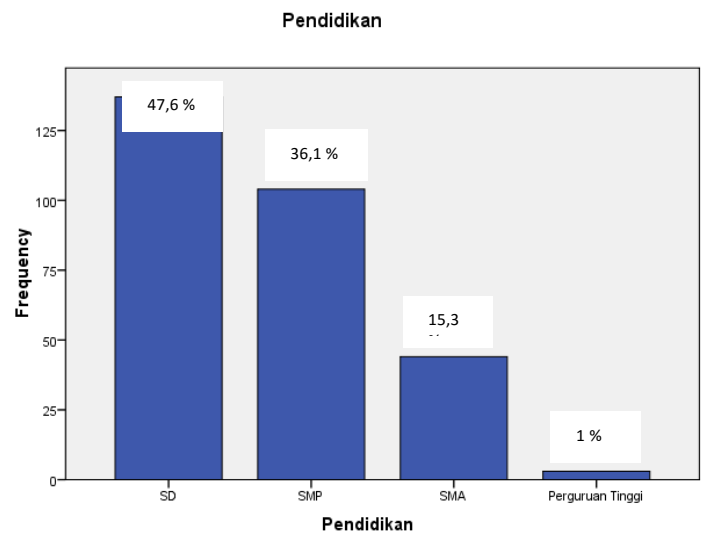

Pendidikan pasangan usia subur dikategorikan menjadi tidak sekolah, SD, SMP, SMA dan perguruan tinggi.

Berdasarkan Grafik 1.2. diketahui bahwa dari 288 (100\%) jumlah responden, persentase kelompok pendidikan yang tertinggi adalah pendidikan dasar yaitu sebanyak 137 responden $(47,6 \%)$, SMP 104 responden $(36,1 \%)$ SMA 44 responden $(15,3 \%)$ dan Perguruan Tinggi 3 responden (1\%)

\section{Grafik 1.3 Distribusi Frekuensi responden berdasarkan pekerjaan}

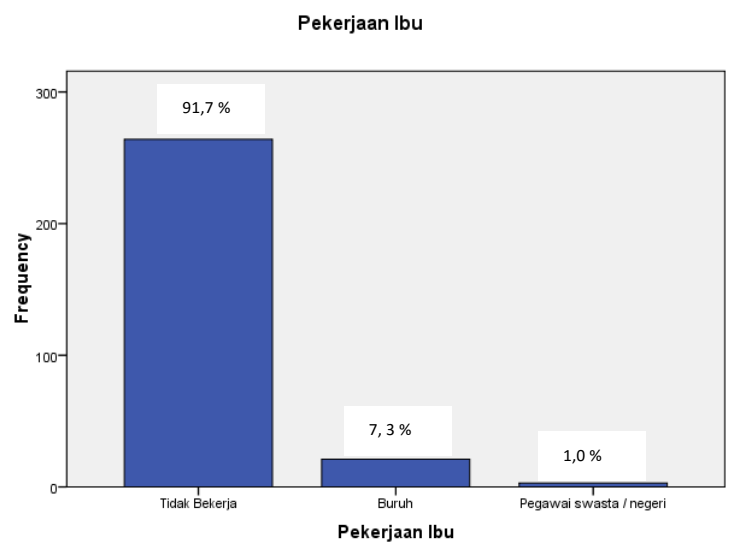

Berdasarkan Grafik 1.3. diketahui bahwa dari $288(100 \%)$ jumlah responden, yang tertinggi berada pada responden tidak bekerja yaitu sebanyak 264 responden $(91,7 \%)$ dan sisanya buruh 21 responden $(7,3 \%)$ dan pegawai swasta / negeri 3 responden $(1,0 \%)$.

\section{Grafik 1.4 Distribusi Frekuensi responden berdasarkan tingkat pengetahuan}

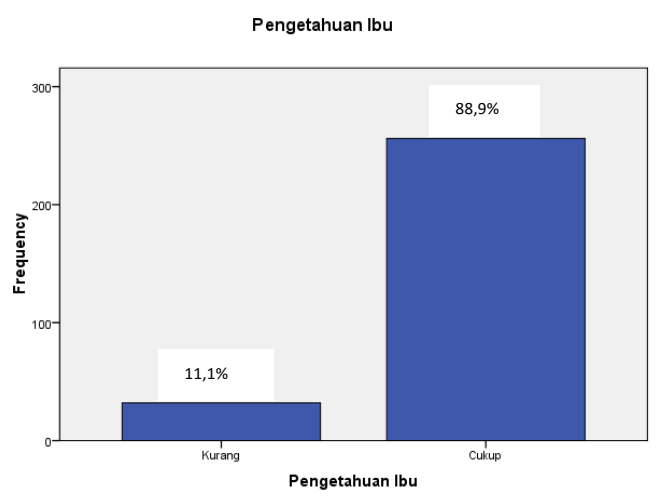

Pengetahuan PUS dikategorikan menjadi Kurang dan cukup.

Berdasarkan Grafik 1.4. diketahui bahwa dari $288(100 \%)$ jumlah responden, yang tertinggi berada pada responden yang berpengetahuan cukup yaitu sebanyak 256 responden $(88,9 \%)$ dan sisanya berpengetahuan kurang 32 responden $(11,1 \%)$.

Grafik 1.5 Distribusi Frekuensi responden berdasarkan dukungan suami 


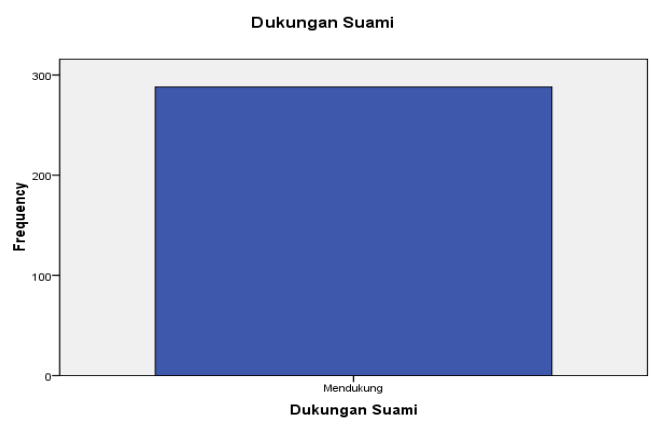

Berdasarkan Grafik 1.5. diketahui bahwa dari $288(100 \%)$ jumlah responden, seluruh pasangan usia subur mendukung istri dalam menggunakan kontrasepsi.

\section{Grafik 1.6 Distribusi Frekuensi responden} berdasarkan tersedianya PLKB

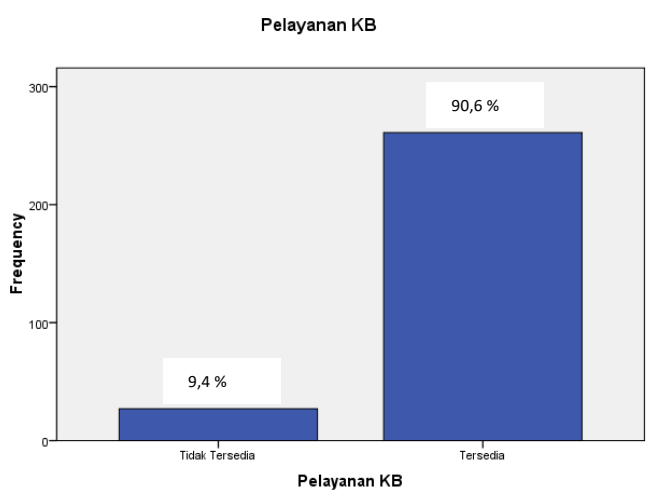

Berdasarkan tabel 1.6. diketahui bahwa dari $288(100 \%)$ jumlah responden, sebanyak 261 responden $(90,6 \%)$ diwilayah tinggalnya terdapat PLKB, dan sisanya sebanyak 27 Responden $(9,4 \%)$ tidak terdapat pelayanan PLKB.

Tabel 1.7 Distribusi Frekuensi responden berdasarkan partisipasi dalam ber-KB

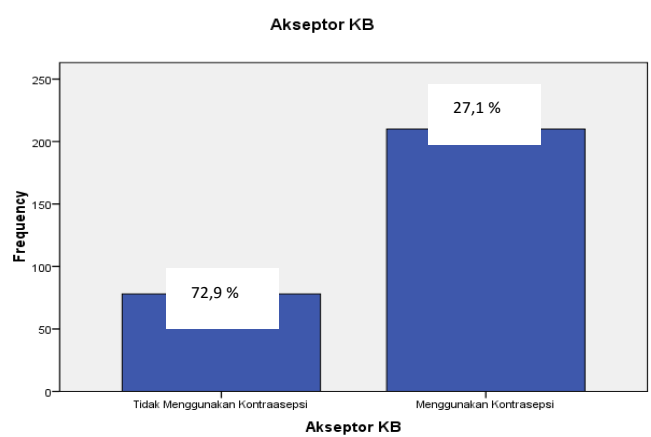

Berdasarkan Ganchart 1.7. diketahui bahwa dari $288(100 \%)$ jumlah responden, tertinggi berada pada responden yang menggunakan
KB yaitu sebanyak 210 responden $(72,9 \%)$ dan sisanya 78 responden $(27,1)$.

\section{Analisis Bivariat}

Distribusi tabel berdasarkan hubungan antar variabel

Tabel 1.1 Pengaruh Umur dan partisipasi KB

\begin{tabular}{|c|c|c|c|c|c|c|}
\hline \multirow{3}{*}{ Umur PUS } & \multicolumn{4}{|c|}{ Partisipasi KB } & \multirow[b]{2}{*}{ Total } & \multirow[b]{2}{*}{$\begin{array}{l}p- \\
\text { value }\end{array}$} \\
\hline & \multicolumn{2}{|l|}{ YA } & \multicolumn{2}{|c|}{ TIDAK } & & \\
\hline & $\overline{\mathbf{F}}$ & $\%$ & $\mathbf{F}$ & $\%$ & $\%$ & \\
\hline Beresiko & 137 & 71,4 & 55 & 28,6 & 192100 & 0,482 \\
\hline $\begin{array}{l}\text { Tidak } \\
\text { Beresiko }\end{array}$ & 73 & 76,0 & 23 & 24,0 & $\begin{array}{ll}96 & 100\end{array}$ & \\
\hline TOTAL & 210 & 72,9 & 78 & 27,1 & 288100 & \\
\hline
\end{tabular}

Kesimpulan Ho Diterima.

Berdasarkan pada tabel 1.1 menunjukkan bahwa pada usia beresiko terdapat 137 responden $(71,4 \%) \mathrm{KB}$ dan 55 responden $(28,6 \%)$ tidak KB, selanjutnya pada usia tidak beresiko terdapat 73 responden $(76 \%)$ $\mathrm{KB}$ dan 23 responden (24\%) tidak KB.

Selanjutnya hasil uji Chi Square pengaruh umur pasangan usia subur dengan partisipasi KB. diperoleh nilai Chihitung sebesar 0,399 dengan nilai signifikansi ( $p$ value) 0,482 . Nilai $p$-value uji lebih besar dari $0,05(0,482>0,05)$ sehingga keputusan uji adalah $\mathrm{H} 0$ diterima, sehingga disimpulkan tidak terdapat pengaruh umur pasangan usia subur dengan partisipasi KB pada PUS di kecamatan rancabali, Almenah Bandung

Tabel 1.2 Pengaruh Pendidikan dengan Partisipasi KB

\begin{tabular}{|c|c|c|c|c|c|c|c|}
\hline \multirow{3}{*}{$\begin{array}{l}\text { Pendidikan } \\
\text { PUS }\end{array}$} & \multicolumn{4}{|c|}{ Partisipasi KB } & \multirow{2}{*}{\multicolumn{2}{|c|}{-Total }} & \multirow{3}{*}{$\begin{array}{l}p \text { - } \\
\text { value }\end{array}$} \\
\hline & \multicolumn{2}{|l|}{ YA } & \multicolumn{2}{|c|}{ TIDAK } & & & \\
\hline & $\overline{\mathbf{F}}$ & $\%$ & $\mathbf{F}$ & $\%$ & $\mathbf{F}$ & $\%$ & \\
\hline SD & 79 & 57,7 & 58 & 42,3 & 137 & 100 & 0,000 \\
\hline SMP & 89 & 85,5 & 15 & 14,5 & 104 & 100 & \\
\hline$\overline{\text { SMA }}$ & 39 & 88,7 & 5 & 11,3 & 44 & 100 & \\
\hline$\overline{\mathbf{P T}}$ & 3 & 1,4 & $\mathbf{0}$ & $\mathbf{0}$ & 3 & 100 & \\
\hline otal & 210 & 72,9 & 78 & 27,1 & 288 & 100 & \\
\hline
\end{tabular}

Ha Diterima 
Berdasarkan pada tabel 1.2. menunjukkan bahwa pada pendidikan dasar terdapat 137 responden, Sebanyak 79 responden $(57,7 \%)$ KB dan 58 responden (42,3\%) tidak KB. Selanjutnya pada pendidikan SMP terdapat 104 responden, 89 responden $(85,5 \%) \mathrm{KB}$ dan 15 Responden $(14,5)$ tidak KB, Pada Pendidikan SMA Terdapat 44 Responden, 39 responden $(88,7 \%) \mathrm{KB}$ dan 5 Responden $(11,3 \%)$ tidak $\mathrm{KB}$, dan pada perguruan tinggi terdapat 3 responden yang $100 \%$ menggunakan KB.

Selanjutnya hasil uji Chi Square pengaruh pendidikan pasangan usia subur dengan partisipasi $\mathrm{KB}$ diperoleh nilai Chihitung sebesar 0,000 dengan nilai signifikansi ( $p$-value) 0,000 . Nilai pvalue uji lebih kecil dari $0,05(0,000$

$<0,05$ ) sehingga keputusan uji adalah $\mathrm{Ha}$ diterima, sehingga disimpulkan terdapat pengaruh pendidikan pasangan usia subur dengan partisipasi KB pada PUS di kecamatan rancabali, Almenah Bandung

Tabel 1.3 Pengaruh Pekerjaan dengan Partisipasi KB

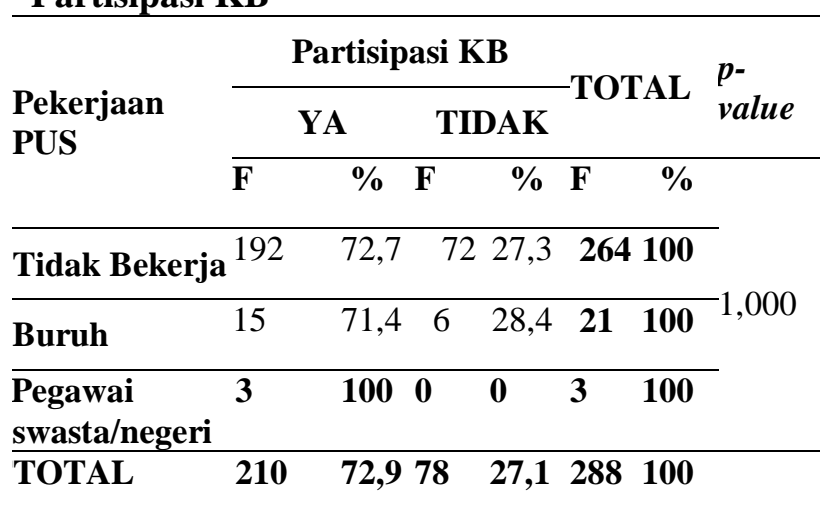

Ho. Diterima

Kesimpulan Ho Diterima.

Berdasarkan pada tabel 1.3 menunjukkan bahwa pada responden PUS yang tidak bekerja terdapat 264 total responden dengan 192 responden $(72,7 \%)$ menggunakan KB dan 72 responden $(27,3 \%)$ tidak $\mathrm{KB}$, pada responden yang bekerja sebagai buruh, terdapat 21 total responden dengan 15 responden $(71,4 \%)$ ber KB dan 6 responden $(28,4 \%)$ tidak ber $\mathrm{KB}$, dan pada responden yang bekerja sebagai pegawai swasta/negeri terdapat 3 total responden dengan 3 reponden (100\%) menggunakan KB
Selanjutnya hasil uji Chi Square pengaruh responden pasangan usia subur dengan partisipasi KB. diperoleh nilai Chihitung sebesar 0,565 dengan nilai signifikansi ( $p$-value) 0,382 . Nilai $p$-value uji lebih besar dari $0,05(0,382>0,05)$ sehingga keputusan uji adalah Ho diterima, sehingga disimpulkan tidak terdapat pengaruh pekerjaan pasangan usia subur dengan partisipasi KB pada PUS di kecamatan rancabali, Almenah Bandung

Tabel 1.4 Pengaruh Pengetahuan dengan Partisipasi KB

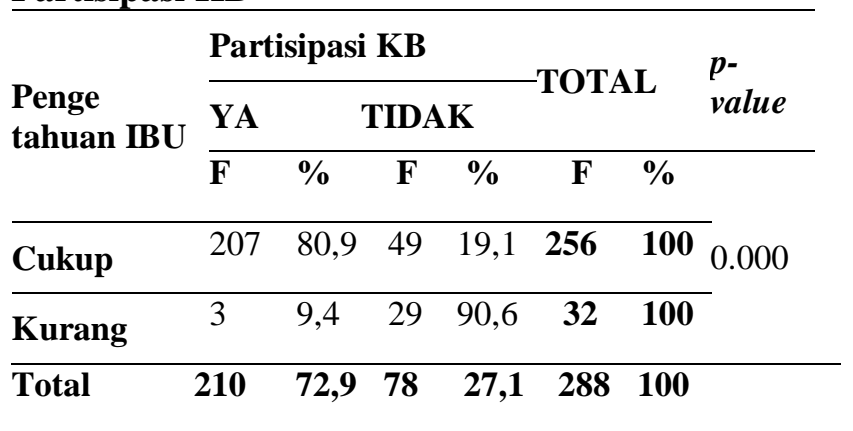

Ha. Diterima

Berdasarkan pada tabel 1.4 menunjukkan bahwa pada responden berpengetahuan cukup terdapat 207 responden $(80,9 \%) \mathrm{KB}$ dan 49 responden $(19,1 \%)$ tidak KB, selanjutnya pada responden berpengetahuan kurang terdapat 3 responden $(9,4 \%)$ KB dan 29 responden $(90,6 \%)$ tidak KB.

Selanjutnya hasil uji Chi Square pengaruh responden pasangan usia subur dengan partisipasi KB. diperoleh nilai Chihitung sebesar 0,810 dengan nilai signifikansi ( $p$-value) 0,000 . Nilai $p$-value uji lebih besar

dari $0,05(0.000<0,05)$ sehingga keputusan uji adalah Ha diterima, sehingga disimpulkan terdapat pengaruh tingkat pengetahuan pasangan usia subur dengan partisipasi KB pada PUS di kecamatan rancabali, Almenah Bandung

Tabel 1.5 Pengaruh dukungan suami dengan Partisipasi KB

\begin{tabular}{llllllll}
\hline \multirow{2}{*}{$\begin{array}{l}\text { Dukungan } \\
\text { Suami }\end{array}$} & \multicolumn{4}{l}{ Partisipasi KB } & & TOTAL & $\begin{array}{l}\boldsymbol{p} \text { - } \\
\text { value }\end{array}$ \\
\cline { 2 - 7 } & YA & \multicolumn{3}{l}{ TIDAK } & & & \\
\cline { 2 - 7 } & F & $\%$ & F & \% & F & \% \\
\hline Mendukung & 210 & 72,9 & 78 & 27,1 & $\mathbf{2 8 8}$ & $\mathbf{1 0 0}$
\end{tabular}


Tidak

0

0

$\begin{array}{ll}0 & 0\end{array}$

0

0 0

TOTAL

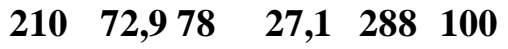

constan.

Berdasarkan pada tabel 1.5 menunjukkan bahwa semua pasangan usia subur mendukung pasangan nya untuk menggunakan KB. Untuk responden yang mendapatkan dukungan dan ber-KB berjumlah 210 responden $(72,9 \%) \mathrm{KB}$ dan 78 responden $(27,1 \%)$ tidak $\mathrm{KB}$.

Dari hasil yang didapat karena seluruh PUS mendukung pasangan untuk ber- KB, maka hasil uji Chi Square tidak dapat dinilai. Dan dinyatakan constan.

\section{Tabel 1.6 Pengaruh PLKB dengan Partisipasi KB}

\begin{tabular}{|c|c|c|c|c|c|}
\hline \multirow{3}{*}{$\begin{array}{l}\text { Penge } \\
\text { tahuan } \\
\text { IBU }\end{array}$} & \multicolumn{3}{|c|}{ Partisipasi KB } & \multirow{2}{*}{-TOTAL } & \multirow{2}{*}{$\begin{array}{l}p- \\
\text { value }\end{array}$} \\
\hline & YA & & TIDAK & & \\
\hline & $\overline{\mathbf{F}}$ & $\%$ & F $\%$ & $\%$ & \\
\hline Tersedia & 207 & 79,3 & $54 \quad 20,7$ & 261100 & 0.000 \\
\hline $\begin{array}{l}\text { Tidak } \\
\text { tersedia }\end{array}$ & 24 & 11,1 & 388,9 & 27100 & \\
\hline
\end{tabular}

Ha. Diterima

Berdasarkan pada tabel 1.6 menunjukkan bahwa pada responden yang PLKB nya tersedia terdapat 207 responden $(79,3 \%)$ $\mathrm{KB}$ dan 54 responden $(20,7 \%)$ tidak KB, selanjutnya pada responden yang akses PLKB tidak tersedia terdapat 3 responden $(11,1 \%) \mathrm{KB}$ dan 24 responden $(88,9 \%)$ tidak KB.

Selanjutnya hasil uji Chi Square pengaruh responden pasangan usia subur dengan partisipasi KB. diperoleh nilai Chihitung sebesar 0,000 dengan nilai signifikansi ( $p$-value) 0,000 . Nilai $p$-value uji lebih besar dari $0,05(0.000<0,05)$ sehingga keputusan uji adalah Ha diterima, sehingga disimpulkan terdapat pengaruh tersedianya akses pelayanan $\mathrm{kb}$ pada pasangan usia subur dengan partisipasi KB pada PUS di kecamatan rancabali, Almenah Bandung

\section{PEMBAHASAN}

\section{Hubungan Antara Umur dengan Akseptor KB}

Penggunaan alat kontrasepsi sangat dipengaruhi oleh umur responden atau pasangan usia subur. Karena umur menentukan tingkat reproduksi seseorang. Umur 20-35 tahun adalah masa dimana alat reproduksi wanita siap dan cukup matang untuk mengandung dan melahirkan seorang anak.

Berdasarkan table 1.1 diketahui bahwa bahwa pada usia beresiko terdapat 137 responden $(71,4 \%) \mathrm{KB}$ dan 55 responden $(28,6 \%)$ tidak KB, selanjutnya pada usia tidak beresiko terdapat 73 responden $(76 \%)$ $\mathrm{KB}$ dan 23 responden (24\%) tidak KB.

Hasil penelitian ini menunjukkan bahwa umur seseorang akan mempengaruhi pemilihan dan pemakaian alat kontrasepsi yang merupakan alat yang baik digunakan untuk menjarangkan kehamilan. Mereka yang umur tidak berisiko mampu mengetahui urutan-urutan pemilihan alat kontrasepsi yang akan digunakan sesuai dengan fase-fase yang ditentukan.

Berdasarkan tabel 1.1 menunjukkan bahwa tidak ada hubungan antara umur dengan akseptor KB. hal ini didasarkan pada hasil uji statistic Chi Square yang diperoleh nilai $p=0,482$ atau $p>0,05$.

Hal ini sejalan dengan penelitian yang dilakukan (Prasetyo 2013) yang mengatakan tidak ada pengaruh umur terhadap pemakaian alat kontrasepsi (Junita, 2009). Namun hal ini tidak sejalan dengan penelitian yang dilakukan Anita yang mengatakan adanya hubungan atau pengaruh antara umur tehadap pemilihan kontrasepsi (Anita, 2014). Hal tersebut juga tidak sejalan dengan Jurnal Ilmiah Bidan dengan judul Faktor - Faktor Yang Berhubungan Dengan Pemilihan Kontrasepsi Pasangan Usia Subur Di Puskesmas Damau Kabupaten Talaud, dimana dijelaskan bahwa terdapat hubungan antara umur dengan pemilihan jenis kontrasepsi. Penelitian yang sama dilakukan oleh Pramono dan Ulfa (2012) di Semarang dimana pada penelitiannya disebutkan bahwa ada hubungan antara umur dengan pemilihan kontrasepsi. 


\section{Hubungan Antara Pendidikan Dengan Akseptor KB.}

Pendidikan adalah salah satu indikator yang mempengaruhi masyarakat dalam upaya persuasi atau pembelajran untuk melakukan tindakan-tindakan (Praktik) untuk mengatasi masalah dan meningkatkan kesehatan. Proses pembelajaran dalam pendidikan dapat mempengaruhi perubahan atau tindakan pemeliharaan dan peningkatan kesehatan.

Pendidikan mempunyai pengaruh positif terhadap tingkat pemakaian kontrasepsi. Berkaitan dengan informasi yang mereka terima dan kebutuhan untuk menunda atau membatasi jumlah anak. Wanita yang berpendidikan tinggi kecenderungan lebih sadar untuk menerima program KB (Notoatmodjo, 2005).

Berdasarkan pada tabel 1.2. menunjukkan bahwa pada pendidikan dasar terdapat 137 responden, Sebanyak 79 responden $(57,7 \%) \mathrm{KB}$ dan 58 responden $(42,3 \%)$ tidak KB. Selanjutnya pada pendidikan SMP terdapat 104 responden, 89 responden $(85,5 \%) \mathrm{KB}$ dan 15 Responden $(14,5)$ tidak KB, Pada Pendidikan SMA Terdapat 44 Responden, 39 responden $(88,7$ \%) KB dan 5 Responden (11,3\%) tidak KB, dan pada perguruan tinggi terdapat 3 responden yang $100 \%$ menggunakan KB.

Hasil penelitian ini menunjukan bahwa ada hubungan antara pendidikan dengan pemakaian alat kontrasepsi. pendidikan seseorang akan mempengaruhi pemilihan dan pemakaian alat kontasepsi yang merupakan alat yang baik digunakan untuk menjarangkan kehamilan. Dengan pendidikan yang tinggi, maka ibu mampu memahami keuntungan dan kerugian dalam pemakaian alat kontrasepsi. Sejalan dengan program pemerintah untuk mempunyai keluarga yang terencana, maka pada masa pendidikannya program keluarga berencana selau dipelajari terutama pada pendidikan menengah dan tinggi lebih detil dibandingkan pada pendidikan rendah (dasar).

Pada tabel 1.2 menunjukkan bahwa ada hubungan antara pendidikan terhadap akseptor KB. Hal ini didasarkan pada hasil uji statistik Chi Square yang diperoleh nilai $p=0,000$ atau nilai $p<0,05$.
Hal ini sejalan degan dengan penelitian yang dilakukan oleh Indah yang pada penelitiannya mengatakan bahwa ada hubungan antara tingkat pendidikan dengan pemilihan kontrasepsi (Indah, 2012). Namun hal ini tidak sejalan dengan penelitian yang dilakukan Pramono dan Ulfa yang mengatakan bahwa tidak ada hubungan yang signifikan antara pendidikan dengan pemilihan kontrasepsi (Pramono dan Ulfa, 2011).

\section{Hubungan antara pekerjaan dengan akseptor KB}

Untuk menunjang kehidupan dan kebutuhan keluarga maka sesorang butuh untuk bekerja. Walupaun pada kenyataan nya bekerja dapat menyita waktu tetapi dapat memberikan pengalaman dan pengetahuan yang baik baik secara langsumg maupun tidak langsung. Lingkungan pekerjaan dapat membentuk suatu pengetahuan karena adanya saling bertukar informasi antara satu sama lainnya (Wawan dan Dewi, 2010). Didalam mendapatkan informasi khususnya mengetahuan tentang KB akan berpengaruh karena biasanya akan didapatkan dilingkungan kerja

Berdasarkan pada tabel 1.3 menunjukkan bahwa pada responden PUS yang tidak bekerja terdapat 264 total responden dengan 192 responden $(72,7 \%)$ menggunakan $\mathrm{KB}$ dan 72 responden $(27,3 \%)$ tidak KB, pada responden yang bekerja sebagai buruh, terdapat 21 total responden dengan 15 responden $(71,4 \%)$ ber KB dan 6 responden $(28,4 \%)$ tidak ber $\mathrm{KB}$, dan pada responden yang bekerja sebagai pegawai swasta/negeri terdapat 3 total responden dengan 3 reponden (100\%) menggunakan KB.

Pada penelitian ini menunjukan tidak ada hubungan antara pekerjaan terhadap akseptor KB.

Hal ini didasarkan pada hasil uji statistik $C h i$ Square yang diperoleh nilai $p=0,382$ atau nilai $p>0,05$.

Hal ini sejalan dengan penelitian Ilyas (2009) di Yokyakarta dengan desain cross sectional didapatkan tidak ada hubungan antara pekerjaan ibu dengan penggunaan alat kontrasepsi, Hal tersebut tidak sejalan dengan Jurnal Ilmiah Bidan dengan judul Faktor - Faktor Yang Berhubungan Dengan 
Pemilihan Kontrasepsi Pasangan Usia Subur Di Puskesmas Damau Kabupaten Talaud. Hubungan pekerjaan dengan pemilihan jenis kontrasepsi menunjukkan ada hubungan antara sosial ekonomi dengan pemilihan jenis kontrasepsi (Lontaan, dkk., 2014).

\section{Hubungan Antara pengetahuan dengan akseptor $\mathrm{KB}$.}

Pengetahuan yang baik tentang kontrasepsi, tentu dapat memberikan peluang, kepada pasangan usia subur untuk dapat memilih kontrasepsi dengan baik dan benar sesuai dengan tujuan ber KB. (Asih dan Hadriah, 2009). Pengetahuan tentang pengendalian keahiran dan keluarga berencana merupakan prasyarat dari penggunaan metode kontrasepsi yang tepat dengan cara yang efektif dan efisien (BPS, etc, 2012).

Pemilihan alat kontrasepsi atau metode $\mathrm{kb}$ sangat dipengarui oleh pengetahuan dengan pengetahuan yang baik pasangan usia subur dapat memilihtempat pelayanan yang baik, metode yang cocok dan nyaman dengan kondisi badan nya. sehingga dengan kesadaran mereka yang tinggi dapat terus memanfaatkan alat kontrasepsi Pengetahuan sebagai domain dari perilaku merupakan awal seseorang untuk melakukan tindakan.

Berdasarkan Tabel 1.4 menunjukkan bahwa pada responden berpengetahuan cukup terdapat 207 responden $(80,9 \%) \mathrm{KB}$ dan 49 responden $(19,1 \%)$ tidak KB, selanjutnya pada responden berpengetahuan kurang terdapat 3 responden $(9,4 \%) \mathrm{KB}$ dan 29 responden $(90,6 \%)$ tidak KB.

Pada penelitian ini menunjukkan terdapat pengaruh tingkat pengetahuan pasangan usia subur dengan partisipasi KB pada PUS. Hal ini didasarkan pada uji statistic Chi Square yang diperoleh nilai $p=0,000$ atau nilai $p<0,05$

Hal ini sejalan dengan penelitian yang dilakukan oleh Rizali yang mengatakan bahwa adanya hubungan pengetahuan responden terhadap penggunaan metode kontrasepsi (Rizali, 2013). Dan juga sejalan dengan penelitian Namun penelitian ini tidak sejalan dengan penelitian yang dilakukan oleh Mardiansyah yang mengatakan tidak ada hubungan pengetahuan responden dengan penggunaan alat kontrasepsi (Mardiansyah, 2014).

\section{Hubungan Dukungan Suami Dengan Partisipasi Kb.}

Pria dan wanita sebagai pasangan suami istri mempunyai tanggung jawab yang sama terhadap penggunaan kotrasepsi. Sehingga pemilihan kontrasepsi sesuai dengan kebutuhan pasangan suami istri. Dengan demikian suami dan istri harus saling mendukung dalam penggunaan kontrasepsi karena keluarga berencana dan kesehatan reproduksi bukan hanya tanggung jawab pria atau wanita saja. Dalam keluarga suami mempunyai peranan penting yakni sebagai kepala keluarga. Suami mempunyai hak untuk setuju ataupun tidak setuju dengan apa yang dilakukan istri. Kecuali jika sang istri memberikan penjelasan atau alasan yang tepat mengenai apa yang dilakukannya sehingga suami mengerti.

Berdasarkan tabel 1.5 menunjukkan bahwa dukungan suami pada PUS bahwa semua pasangan usia subur mendukung pasangan nya untuk menggunakan kb. Untuk responden yang mendapatkan dukungan dan ber-KB berjumlah 210 responden $(72,9 \%)$ KB dan 78 responden $(27,1 \%)$ tidak KB.

Dari hasil yang didapat karena seluruh PUS mendukung pasangan untuk ber- KB, maka hasil uji Chi Square tidak dapat dinilai. Dan dinyatakan constan.

\section{Hubungan Peran PLKB dengan partisipasi KB.}

Petugas kesehatan menjadi salah satu pihak yang paling bertanggung jawab dalam mengkampanyekan program keluarga berencana kepada masyarakat. Tetapi dalam perkembangannya tugas tersebut tidak dapat terlaksana dengan baik. Petugas kesehatan juga tidak memiliki dana yang cukup untuk program tersebut sehingga mereka hanya dapat melayani para calon akseptor yang datang ke puskesmas. Saat di puskesmas inilah petugas kesehatan memegang peranan penting karena mereka dapat meyakinkan para calon akseptor untuk memakai alat kontrasepsi.

PLKB/PKB merupakan ujung tombak pengelola $\mathrm{KB}$ di lapangan. Undang-Undang Republik Indonesia No. 52 tahun 2009 tentang Perkembangan Kependudukan dan Pembangunan Keluarga dan Peraturan 
Presiden No. 62 tahun 2010 tentang Badan Kependudukan dan Keluarga Berencana Nasional menyatakan bahwa BKKBN mempunyai tugas melaksanakan tugas pemerintah di bidang pengendalian penduduk dan penyelenggaraan keluarga berencana, agar amanat tersebut dapat terimplementasikan perlu ditetapkan Norma, Standar Prosedur dan Kriteria (NSPK) di bidang pengendalian penduduk dan penyelenggaraan keluarga berencana (UUD, 2009).

Berdasarkan Tabel 1.6 menunjukkan bahwa pada responden yang PLKB nya tersedia terdapat 207 responden $(79,3 \%)$ KB dan 54 responden $(20,7 \%)$ tidak KB, selanjutnya pada responden yang akses PLKB tidak tersedia terdapat 3 responden $(11,1 \%) \mathrm{KB}$ dan 24 responden $(88,9 \%)$ tidak KB.

Pada tabel 1.6 menunjukkan bahwa ada hubungan antara peran PLKB terhadap akseptor KB pada pasangan usia subur dengan partisipasi KB pada PUS di kecamatan rancabali, Almenah Bandung Hal ini didasarkan pada hasil uji Chi Square diperoleh nilai Chihitung sebesar 0,000 dengan nilai signifikansi ( $p$-value) 0,000. Nilai $p$-value uji lebih Kecil dari 0,05 (0.000 $<0,05)$ sehingga keputusan uji adalah $\mathrm{Ha}$ diterima.

Hal ini sejalan dengan penelitian yang dilakukan oleh Junita yang mengatakan bahwa dukungan petugas kesehatan berpengaruh terhadap pemakaian alat kontrasepsi. Petugas kesehatan berperan dalam memberikan informasi, penyuluhan dan menjelaskan alat kontrasepsi (Junita, 2009).

\section{SIMPULAN}

Berdasarkan hasil penelitian dan analisis data yang dilakukan di desa Alamendah, kecamatan rancabali, kabupaten bandung, didapatkan hasil, terdapat hubungan antara pengetahuan, pendidikan, dan peran PLKB dengan akseptor KB, dan tidak ada hubungan antara pekerjaan, usia dan dukungan suami dengan akseptor KB.

\section{SARAN}

1. Bagi Tenaga kesehatan

\begin{tabular}{llll} 
Diharapkan & \multicolumn{2}{r}{ untuk } & \multicolumn{2}{r}{ melakukan } \\
penyuluhan & KB lebih & sering demi
\end{tabular}

peningkatan pengetahuan alat kontrasepsi dimasyarakat.

2. Untuk Pasangan Usia Subur. Lebih meningkatkan pengetahuan tentang $\mathrm{KB}$ melalui sumber-sumber pengetahuan, selain dari tenaga kesehatan, seperti dari media massa, dan media elektronik

3. Bagi Institusi diharapkan hasil penelitian ini dapat dijadikan referensi dan sumber pembelajaran untuk mahasiswa dan teman sejawat.

4. Bagi Peniliti

Untuk peneliti selanjutnya diharapkan dapat digunakan sebagai salah satu sumber data untuk penelitian selanjutnya dan dilakukan penelitian lebih lanjut berdasarkan faktor lain, variabel yang berbeda jumlah sampel yang lebih banyak dan tempat yang berbeda desain yang lebih tepat yang berhubungan dengan alat kontrasepsi keluarga berencana.

\section{DAFTAR PUSTAKA}

Anita, Lontaan. 2014. Faktor-faktor Yang Berhubungan dengan Pemilihan Kontrasepsi Pasangan Usia Subur di Puskesmas Damau Kabupaten Talaud. Jurusan Kebidanan Politeknik Kesehatan Kemenkes, Manado. Jurnal Ilmiah Bidan. Volume 2, Nomor 1, ISSN : 2339-1731

Anjum, S., Durgawale, P.M., \& Shinde, M. (2014). Epidemiological Correlates of Use of Contraceptive Methods of Appraisal of Health Education on Status of Knowledge and Practices among Married Woman. International Journal of Science and Research, 3, 203.

Asih, Leli., Hadriah Oesman. 2009. Analisa Lanjut SDKI 2007: Faktor-faktor yang Mempengaruhi Pemakaian Kontrasepsi Jangka Panjang (MKJP). Jakarta: BKKBN.

Badan Pusat Statistik (BPS), Badan Kependudukan dan Keluarga Berencana Nasional (BKKBN), Kementrian Kesehatan, MEASURE DHS ICF International. 2012. Laporan Pendahuluan SDKI 2012. Jakarta: 
BPS, BKKBN, Kemenkes, ICF International

BKKBN. (2015). Jumlah Peserta KB Aktif Menurut Metode Kontrasepsi Cara Modern: Data tahun 2014. Surakarta: Dinas Kesehatan Sukoharjo.

BKKBN. 2016. Membangun dan menerapkan budaya kerja organisasi secara konsisten. Jakarta: BKKBN

Indah. 2012. Hubungan Sosial Ekonomi dan Karakteristik Akseptor dengan Tingkat Kemandirian Peserta Baru. Skripsi. Medan: USU.

Junita, T.P. 2009. Faktor-Faktor Yang Mempengaruhi Pemilihan jenis Kontrasepsi Yang Digunakan Pada Pasangan Usia Subur (Karya Tulis Ilmiah). Semarang: FKM UNDIP

Kemenkes 2013. Situasi keluarga berencana di Indonesia. Jakarta.

Kurnia, dkk. 2008. Pengetahuan Kontrasepsi pada Suami ditinjau dari Umur, Pendidikan dan Pekerjaan. Jurnal. Surabaya: Universitas Airlangga

Lontaan, dkk., 2014. Faktor - Faktor Yang Berhubungan Dengan Pemilihan Kontrasepsi Pasangan Usia Subur Di Puskesmas Damau Kabupaten Talaud. Jurnal Ilmiah Bidan. Volume 2 Nomor 1. Januari - Juni 2014.

Mardiansyah. 2014. Analisis Faktor yang Berhubungan dengan Penggunaan Alat Kontrasepsi Pada Pasutri di Kelurahan Tamalanrea Indah Kecamatan Tamalanrea Kota Makassar. Skripsi. Fakultas Kesehatan Masyarakat. Universitas Hasanuddin. Makassar.

Notoatmodjo, S. (2010). Metodologi Penelitian Kesehatan. Jakarta: Rineka Cipta

Notoatmodjo, S. (2012). Promosi Kesehatan dan Perilaku Kesehatan. Jakarta :Rineka Cipta.

Pramono, dan Ulfa. 2011. Analisis Faktorfaktor Yang Mempengaruhi Pemilihan AKDR. Skripsi. Semarang: Stikes Telogorejo.
Rizali, M.I. 2013. Faktor Yang Berhubungan Dengan Pemilihan Metode Kontrasepsi Suntik Di Kelurahan Mattoangin Kecamatan Mariso Kota Makassar Tahun 2013. Makassar : Fakultas Kesehatan Masyarakat Universitas Hasanuddin.

Syukur, A., Dkk 2010. Indonesia dalam arus sejarah, Jakarta, PT. Ikhtiar baru Van Hoeve.

Uud 2009. Undang-Undang Republik Indonesia No. 52 tahun 2009 tentang Perkembangan Kependudukan dan Pembangunan Keluarga

Wawan. 2010. Teori dan Pengukuran Pengetahuan, Sikap dan Perilaku Manusia. Yogyakarta : Nuha Medika

Wikojoastro, H. 2013. Ilmu Kandungan, Jakarta, PT. Bina Pustaka Sarwono Prawirohardjo.

Wijayanti, dkk. 2009. Penyuluhan KB Vasektomi terhadap Minat Pria dalam ber-KB Vasektomi diwilayah kerja Puskesmas Sukorame Kota Kediri. Jurnal. Malang : Poltekkes Depkes Malang

Zainuddin, E. 2012. Faktor Yang Berhubungan Dengan Pemilihan Metode Kontrasepsi Efektif Terpilih (MKET) Pada Akseptor KB Di Kelurahan Tonasa Kecamatan Balocci Kab. Pangkep Tahun 2012. . Skripsi Sarjana, Universitas Hasanuddin. 